\title{
The individual's invention: for a study of cultural sociology of self
}

\author{
A invenção do indivíduo: para um estudo da sociologia cultural do eu \\ La invención del individuo: para un estudio de la sociología cultural del yo
}

\author{
Daniel Gutiérrez Martínez ${ }^{1}$
}

\begin{abstract}
This paper aims to frame a few ideas and concerns about the way western societies in general during modernity times, have been handled through multicultural theories and public policies, the issue of cultural diversity, and especially those ones dealing with the interaction among different cultural groups. We assume that the different forms in which public policies are back up in a theoretical level, by then built and applied to different cultural communities (materialistic level) represent and reflect an ontological conception of culture (symbolic level) based in the belief of the existence of an autonomous, conscientious and rational individual moral subject. We argue that today, these policies are the last political crystallization of this "cult of the individual" that has been shaping over the last two centuries a system of beliefs about the human social being and group relations. This is a soteriological logic of the projection whose origins are of dramatic character (morality of good or bad). This has to do with what here is called the sociology of Self, which means analyse the implications of a system of beliefs based on the cult of the individual on scientific reasoning and forms of political organization of society, and how the interaction structures result as the meaning of action and experience for people and human group: in other words, it is about the production of social meaning. I used the metaphor of Tribal awareness as the main notion of this approach. It is a vitalism of tragic existential origin, which is the nodal point of philosophy in Nietzsche. From a cultural sociological approach of imaginary this would mean investigating the collective effects of a system of beliefs that sacralised the human being as individualistic entity and considering the effects of collective meanings when the individual becomes a cultural icon with a historical global scope.
\end{abstract}

Keywords: Tribal awareness. Cult of individual. Iconic individualism. Inter-subjectivity. Cultural policies.

\section{Resumo}

Este artigo tem como objetivo apresentar algumas ideias e preocupações sobre o modo como as sociedades ocidentais em geral, durante a modernidade, foram tratadas por meio de teorias multiculturais e políticas públicas, bem como a questão da diversidade cultural e, especialmente, aquelas que lidam com a interação entre diferentes grupos culturais. Assumimos que as diferentes formas em que as políticas públicas estão respaldadas em um nível teórico, então construído e aplicado a diferentes comunidades culturais (nível materialista), representam e refletem uma concepção ontológica de cultura (nível simbólico) baseada na crença da existência de um sujeito moral autônomo, consciencioso e racionalindividual. Argumentamos que, hoje, essas políticas são a última cristalização política desse "culto do indivíduo" que vem moldando, nos últimos dois séculos, um sistema de crenças sobre o ser humano social e as relações grupais. Esta é uma lógica soteriológica da projeção cujas origens são de caráter dramático (moralidade do bem ou do mal). Isso tem a ver com o que aqui se chama de sociologia do Self, que significa analisar as implicações de um sistema de crenças baseado no culto do indivíduo ao raciocínio

1 Professor-pesquisador do Colegio Mexiquense, na Cidade do México, e doutor em Sociologia pelo Colegio de México e pela École des Hautes Études en Sciences Sociales, de Paris. e-mail: zocoytl@yahoo.com

Comun. \& Inf., Goiânia, GO, v. 21, n. 2, p. 87-123, jun./set. 2018. 
científico e às formas de organização política da sociedade e como as estruturas de interação resultam no significado de ação e experiência para pessoas e grupos humanos: em outras palavras, trata-se da produção de significado social. Eu usei a metáfora da consciência tribal como a principal noção dessa abordagem. É um vitalismo de origem existencial trágica, que é o ponto nodal da filosofia em Nietzsche. A partir de uma abordagem sociológica cultural do imaginário, isso significaria investigar os efeitos coletivos de um sistema de crenças que sacralizou o ser humano como entidade individualista, considerando os efeitos de significados coletivos quando o indivíduo se torna um ícone cultural de âmbito histórico global.

Palavras-chave: Consciência tribal. Culto do indivíduo. Individualismo icônico. Intersubjetividade. Políticas culturais.

\section{Resumen}

Este trabajo pretende enmarcar algunas ideas y preocupaciones sobre la forma en que las sociedades occidentales en general durante la modernidad, han sido manejadas a través de teorías multiculturales y políticas públicas, el tema de la diversidad cultural, y especialmente las relacionadas con la interacción entre diferentes grupos culturales. Suponemos que las diferentes formas en que las políticas públicas se respaldan en un nivel teórico, para entonces construidas y aplicadas a diferentes comunidades culturales (nivel materialista) representan y reflejan una concepción ontológica de la cultura (nivel simbólico) basada en la creencia de la existencia de un sujeto moral individual autónomo, consciente y racional. Argumentamos que hoy, estas políticas son la última cristalización política de este "culto al individuo" que ha ido configurando en los últimos dos siglos un sistema de creencias sobre el ser social humano y las relaciones grupales. Esta es una lógica soteriológica de la proyección cuyos orígenes son de carácter dramático (moralidad del bien o del mal). Esto tiene que ver con lo que aquí se llama la sociología del Ser, que significa analizar las implicaciones de un sistema de creencias basado en el culto del individuo sobre el razonamiento científico y las formas de organización política de la sociedad, y cómo las estructuras de interacción resultan como el significado de acción y experiencia para las personas y el grupo humano: en otras palabras, se trata de la producción de significado social. Utilicé la metáfora de la conciencia tribal como la noción principal de este enfoque. Es un vitalismo de origen existencial trágico, que es el punto nodal de la filosofía en Nietzsche. Desde un enfoque sociológico cultural de lo imaginario esto significaría investigar los efectos colectivos de un sistema de creencias que sacralizó al ser humano como entidad individualista, y considerando los efectos de los significados colectivos cuando el individuo se convierte en un icono cultural con un alcance histórico global.

Palabras clave: Conciencia tribal. Culto al individualismo. Individualismo icónico. Intersubjetividad. Políticas culturales.

\section{INTRODUCTION}

$\mathrm{n}$ a memorable conference the German philosopher Heidegger (1973) said that self-
production of men produces the danger of self-destruction. He was referring to
Marxism's materialistic presupposition. For him Marxism's insight about social meaning and individual interaction within society starts with the postulate that societies are a production of themselves and they lead to the self-production of man as an individual being, i.e. 
the production of self-destruction. By thinking along these lines, Marxist thought seems to correspond to everyday life in most of social science analyses, mostly if we talk about the concept of culture where self-production really seems to govern men and society. Culture is a creative process of self-production, because is collective, but self-production of men may be a self-destruction. Even if the Marxism forms of expression have changed in the last two hundred years they still continue influencing contemporary thought, giving significance to the selfproduction of men and society itself, mostly if we do reference to the concept of individualism. If we allow exceptions for some sociological thinkers who focus on cultural structures as elements of social meaning in what are called a strong cultural sociology program (ALEXANDRE; SMITH, 2003), or even other thinkers who emphasized the role of social imaginary (GRASSI, $2008)^{2}$ in the constitution of social ideas, certainly we can say that social sciences in the way they organize and analyse society have not changed a lot from this materialistic Marxist perspective in the last one hundred years. In general, sociology has remained in its materialistic bubble thinktank where the main object of study seems to be the Self, but not in the sense of a collective meaning, or as solidarity element but as an individual moral category (DUMONT, 1983). ${ }^{3}$ This is not new, if we remember Durkheim's "social divine" concept in his book about Division labour society, he talks about the individual as a sacred element of modernity. "Durkheim suggested the individual has become the only really sacred thing: people worship the "cult of the individual'" (ALEXANDER, 2006, p.18). ${ }^{4}$

Almost one hundred years after these assertions, we can say without doubt that the cult of individual (individualism) is not only prevailing but also is even stronger and well consolidated, not only in the sociological theories of culture but in the collective imaginary of the day to day. ${ }^{5}$

\footnotetext{
2 Authors like Bachelard, Bergson, Durand, Simmel, Maffesoli.

${ }^{3}$ We must define the concept of human being as an individualistic entity under two main assertions: 1) the first refers to an empirical subject (a sociodemographic arbitrary concept) an indivisible sample of the human species, as we may find physically in all societies; and 2) a moral, independent, autonomous and thus (essentially) non-social entity, as we encounter in modern ideology of society (an ideological-moral arbitrary concept). This is a crucial distinction in sociology. The ideological concept of individual is which has had greater impact in organization of modern societi es. It is apparent that it is an arbitrary concept with contentmoralists who have also determined most of the sociologic al theories since the beginning.

${ }^{4}$ As Alexander wrote, even if Durkheim talked about notions of solidarity or "non-contractual elements of contract" he did not conceptualize very well how it actually happened, or even what society itself is"

${ }^{5}$ This applies even to the proposal of symbolic anthropology whose notion of culture is certainly dynamic but remains centered on a moralistic notion of the individual. Who would claim that the definition of the human being as an individual entity is mere fiction? Who would claim that individualism is an ideology of modernity that has come to conform as a belief system in today's world?
}

Comun. \& Inf., Goiânia, GO, v. 21, n. 2, p. 87-123, jun./set. 2018. 
Durkheim clearly saw individualism (the cult of individual) as social value, but he did not sufficiently accentuate the distance between the modern vision of humanity and the possible perspectives of the others times and geographies. It is true that in some passages of Elementary Forms, Durkheim imagined modern society as a type of "social effervescence" of community like those referred to Australian tribes, which by the way, he never visited. In addition we can affirm that predominant classical sociology in its beginnings was itself a production of the individual's cult, and the self-production of society that wanted to analyse and build an individualistic society (MARTUCCELLI, 1999). ${ }^{6}$

The strong questioning by the inheritance of the social sciences towards the cult to the individual as a great issue of social analysis would not have had any questioning at the epistemological or theoretical level, if it would not have had a direct impact on the political organization of the societies in the modern world, with the disastrous results well known in terms of human welfare and in terms of the false Promethean promise of the individual emancipation for everyone: a sort of sacred paradise on earth (DELUMEAU, 2005). However, the most interesting aspect about this is that the individualism seems to be an icon of a modern system of beliefs that has been nourishing the modern imagination and imaginary of western societies for eons. $^{7}$ Indeed, here it is assumed that modern public policies, primarily the cultural ones, are based on the cult of the individual. It is also true with ancient republican policies; but even if they come from different cultural traditions (Latin and Anglo-Saxon cultures) they derive their legitimacy (if there is any) from the same individualistic principles: autonomous, rationality, one single entity. The main idea that motivates these reflections is the predominant presence of scientific cultural theories in social academy, but also in the political practices and sociological literature in general referring the human being as an individualistic icon, and not as a collective

\footnotetext{
${ }^{6}$ There are several sociological thinkers in Durkheim's time whose influence was limited, and who did not base their theories on the individual cult, but in the mimetic contamination (Gabriel Tarde) or anomy as a creative characteristic of peripheral humans groups (Jean Marie Guyau -the precursor of anomy concept before Durkheim) without forget the everlasting sociologist George Simmel. This discussion could even go deeper into the past if we recall several authors such as: Nietzsche, Baudelaire, or the contemporary Manheim. On the other hand, this is not the right moment to consider who would be the latest materialistic representative sociologist, but it is probable that the most emblematic and recent one that exemplifies this materialistic sociological tradition would be Pierre Bourdieu.

${ }^{7}$ The image, in the sense of a symbolic image, is the simple unity of the imaginary, a dynamic system organizing the founding instincts of meaning, which allows the necessary relation between man and the environment. The imagination is the process through which representation and symbolic transfiguration is accomplished. The imaginary is the capacity, the strength of this transformation of representation, the faculty of symbolization from which all fears, hopes and cultural fruits have been continuously springing since Homo erectus stood on earth.
}

Comun. \& Inf., Goiânia, GO, v. 21, n. 2, p. 87-123, jun./set. 2018. 
awareness entity. In other words, we notice that the vast majority of sociological theories of culture find their roots in a dramatic approach of society, and little less refer to a tragic prospective of the world. ${ }^{8}$ It has to be considered that there is a tendency to enclose in a single topic the reflections around the cultural pluralism, the multicultural theories and the interculturality approaches reducing these notions to the analysis of the political management of the difference, instead of a scientific study of the social diversity i.e. collective inter-subjectivity.

Here is about the way western societies in general, have been handled through liberal and communitarian theories and public policies, the issue of cultural pluralism, especially the ones dealing with the interaction among different cultural groups. We assume that the different forms in which public policies are conceptualized, built and applied to different cultural communities (materialistic level) represent and reflect an ontological dramatic conception of culture (symbolic level) based in the belief of the existence of an autonomous, conscientious and rational individual moral subject. Here is argued that cultural policies today are the last political crystallization of this "cult of the individual" that has been shaping over the last two centuries a system of beliefs about the human social being and group relations. ${ }^{9}$

Today, this is not only a matter of politicians who design multicultural public policies, but it is also a concern of the social science theories that support them. And this not only concerns multicultural state nations but modern westerns societies in the current world. These observations remind us of that the modern system of beliefs is a global "cult of the individual" that establishes frontiers between the post metaphysical version of the rational sacred individualism and the postmodernist iconic individualism. In others words the central element that defines culture in the hegemonic social sciences in western societies, is that it is assume that human being is an individual, and the groups are the result of the addition gathering of individuals (Rousseau's Social Contract). That is called the "methodological individualism" (BOUDON, 1982).

\footnotetext{
${ }^{8}$ The monistic thought, with its varied historical declensions, preferred the drama, a representation that can have different levels of intensity and pathos, but which ends up unmistakably. Everything else is the tragic, which remains in doubt, in the impossibility of conciliation, which is the eternal condition of our human existence and of our knowledge of the world.

${ }^{9}$ We can also say that the roots of this belief system extend back 2500 years with the rise of monotheistic thought, the unification of rational thought (Euclid and Hypocrites) and the extension of soteriological morality (Hellenism from IV-VI B.C., Babylon civilization, Rome Empire). This is another philosophical discussion that is not going to be a topic in this work.
}

Comun. \& Inf., Goiânia, GO, v. 21, n. 2, p. 87-123, jun./set. 2018. 
The considerations above have to do with what we call the sociology of Self, which means in one hand analyse the implications of a system of beliefs based on the cult of the individual on scientific reasoning and forms of political organization of society and, on the other hand, the way in which Self formed the social meaning, starting from the symbolic signification that implies belonging to a community. In other words, it is a matter of how the interaction structures the meaning of action and experience in peoples and human groups (ALEXANDER, 2006).

In this debate the actions of the individual are considered as rational, with full conscience of his/ her interests and with a considerable autonomy from the decisions of the other groups. He is supposed to be capable to rationalize his decisions about what is good and wrong (i.e. a moral sacred and profane schema) for him and his environment based in the emancipation principle. As if the individual has the possibility to control every aspect of life (dramatic point of view). Moreover, the individual may be conceptualized as an entity determined by their group membership; in the best of cases the individual actions are defined in a simultaneous feedback movement between these two logics just mentioned. This, thus far, is what we may call the multicultural theoretical debates between communitarian and liberalism perspectives. The sociology of self proposes further analysis of these two perspectives, the way social meaning is structured within societies when considered as the foundation of social interaction what I call the Tribal awareness. ${ }^{10}$

In a cultural sociological approach (ALEXANDER; SMITH, 2003, p. 5) ${ }^{11}$ and based in a sociology of imaginary (GRASSI, 2008), this would mean on one hand investigating the collective effects of a system of beliefs that sacralised the individual, and on the other hand, considering the effects of collective meanings when the individual becomes a cultural icon with a historical global scope. Just to give some short examples of this, when State-nations in modern

\footnotetext{
${ }^{10}$ The metaphor of tribalism in the social sciences is much more heuristic to outline the group relationships of loyalties, trusts, unions that directly touch the bottom of collective emotions, better than communitarianism and the collective concepts. Tribalism can be an emotional group much more perennial than the collectivism, or much more ephemeral than communitarianism. It can be a simple feeling of belonging that engenders collective actions without any specific function or objective. It is more viscous and palpable at the same time as communitarianism and collectivism, which are more political in nature. In short, it is the relationship of collective effervescence that defines us as human groups since the human being is a society.

${ }^{11}$ This approach include various disciplines that have been called the sociology of knowledge, the sociology of art, the sociology of religion, the sociology of ideology that drive to paid respect primarily the significant effects of collective meanings tracing the moral textures and delicate emotional pathways by which individuals and groups come to influenced by them.
}

Comun. \& Inf., Goiânia, GO, v. 21, n. 2, p. 87-123, jun./set. 2018. 


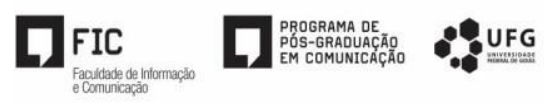

western world use the notion of Citizen (this means the rights and responsibilities of an individual integrated within a sacred collectiveness called Nation) to express a moral political value we are talking in terms of cult of the individual. We can argue the same with the organization of the economy in individual incomes, salaries, consumption, etc. The political sphere organized around individual votes in a "democratic society" represents another case with the same meaning. There is a lot to say about the normative and rules organization from the individualistic point of view in modern societies starting from an institutional level. Moreover, when we analyse today all the production of the personalization of intimacy (piercing, tattoo, spa or even the mass media or ICTs - Infra.), in public sphere in contemporary and postmodern societies we are talking about iconic individualism from institutional level, and as an individual iconicity from an instituting point of analysis. For us all these examples means at an analytical level the production of the selfproduction of the individual entity (cult of individual and iconic individualism in in modern societies and individual iconicity in postmodern societies).

In this sense we can argue that since the Spirit of modernity (at the epistemological level), through modern cultural theories, the economic political and social organization of societies with the specify policies of respect and recognition of cultures (multiculturalism) has been conceived from the point of view and principles of an iconic individualism i.e. a political cult of individual which means that what it is privileged here is the question of individual meanings added and how the ideal structures of culture are formed by other structures or materialistic levels. Here the primitive importance of collective symbolism is considered to be of a second order.

We argue that what is called inter-subjectivity represents a way not only to make policies using a cultural sociological approach and a sociological of imaginary emphasis, but also to reflect an epistemological way of thinking in which the individual does not exist as a sacred entity. The inter-subjectivity approach privileges the analysis of interaction in its collective meaning considering the collective-tribal human awareness. This awareness may be conscious or unconscious, thought or felt, reasoned or lived, but certainly is the basis of all social foundation. In this way we look forward to analysing the logic of the inter-subjectivity theories in everyday life, in particular in what concerns the cultural diversity interaction. We define that intersubjectivity refers to the dynamic enabling exchanges and reciprocal relationships among people 


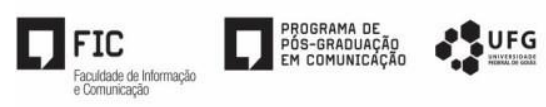

and groups with a Tribal awareness of their selves and their surroundings. That is what we call inter-subjective social meaning.

\section{DIFFERENCE, INDIVIDUALISM AND DIVERSITY THEORIES}

Indeed the usual references controversies about cultural concepts have to do, most of the time, with the collective and communitarian aspects of interactions, in which the topic of minorities, ethnic groups and social movements are part of the central debate. In this debate we have arguments that critique the multicultural approach, for example argue that a multicultural society annihilates the individual to the benefit of collective actions, and in that sense pushes people to renounce their particular identities. For the detractors of these arguments this multicultural logic represents the most important pluralistic threat for democratic societies and modern socio-political systems.

Multiculturality appears here as a system of thought that is supposed to be in fundamental contradiction with the principles of individualism. Certainly the strategies and political actions promoted by the multicultural paradigm seek to protect native cultures, strengthen community ties, and support groups by category, all this presupposing that being part to collectiveness is essential. But this does not mean that the paradigm is in a contradiction with the individualistic principle of modernity. On the contrary it is the crystallization of it, because these strategies explicitly contain the specific idea that, in order to be considered as an individual the citizen has to be a member of a particular community. In this sense, paradoxically, it appears that the pursuit of the liberation of the individual in this multicultural contemporary movement has to pass through the reference of origin of the culture. Indeed in a movement that could be characterized as post-modern, people tend to claim their rights in terms of being "members" of a community. In this way they relate readily to an ethnic, religious, linguistic or memorial group in order to get spontaneously the materialistic and individual benefits. Suddenly this collective cultural claim appears elsewhere the framework of the nation state where the ethnic groups seem to be the essential issue. This is why we postulate that multiculturalism is within the framework of the State that particularly privileges individualistic principles of action. It is therefore clear that multiculturalism as a modern paradigm defends the foundational liberal value of individualism. The promotion of cultural differences has nothing to do with the development of the individual 


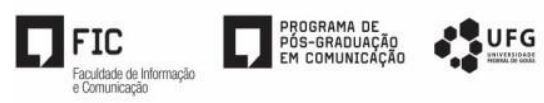

person by exploring the specificities of his own culture. This promotion actually would fit in a widely shared and comprehensive political strategy. But it is questionable in the sense that the specificities of everybody culture hang the values of individual autonomy. At the end the objective it is to ensure the individual freedom. That is how some thinkers, espousing liberal values and adapting to a multicultural reality, that they rejected liberal sectarianism and formed the multiculturalist current.

These currents suppose that the multicultural demands related to the ethnic groups appeal to the individual ethic, instead of arguing that individualism is at the centre of multicultural reflections and is the motor of these philosophical and political thought, as Charles Taylor shows with his recognition of identities notion, in which he found a structural link between the development of principles of the individual in modern societies and the multicultural demands of minorities and different ethnic groups. From Herder to Rousseau, Taylor rebuilt in a political philosophical reflection the pathway that drove Western culture to the contemporary iconic individualism.

We can mention several schematics and classical perspectives that range from sociological and philosophical schemas to socio-political level, that follow the same arguments. As we have already mentioned durkheimian sociological thought argues that the loss of individual autonomy is the price that must be paid for social autonomy. The German tradition as well, aims to show the individual autonomy against social structures, highlighting the multiplicity of links that connects the individual to the group and society. The current sociological attitude is to consider the individual development as a process in opposition to the traditional social functionalism. All those perspectives certainly differ in the way they evaluate the individual process in modern societies, but they have the tendency to consider the development of individualism and the social link as incompatibles, not only in a social political sense, but also from a theoretical perspective (LASCH, 1979; LIPOVETSKY, 1983; SENNET, 1979).

If we consider other classical contexts in a predominantly liberal tradition, it is possible to follow the link between the individualistic logic (dramatic perspective) and the social organization; from Locke to the actual philosophical analysis all discussions are consistent with the definition of the individual as an abstract entity, in which it is possible to analyse him in terms of his ideological or intellectual function or in terms of his moral judgments process. All this is

Comun. \& Inf., Goiânia, GO, v. 21, n. 2, p. 87-123, jun./set. 2018. 


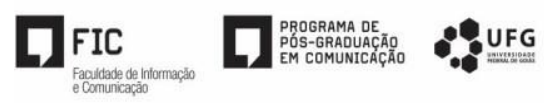

located in an absolute social meaning. In this sense the arguments follow the terms of individual logical procedures. The implicit argumentation that exists in these perspectives is that the individual is an autonomous moral entity separated by a strong discontinuation with other individuals as well as the natural and social contexts surrounding him.

It is clear that most of the Anglo-Saxon cultural political theories in the last century were fed by this liberal philosophical tradition. The individual is seen as rational and responsible for his actions, which are carried out with the control of emotions. Here the individuals' acts are considered as a free will, with social meaning being totally autonomous from historical, cultural and traditional conditions. It supposes that the individual manages his life space and his identity sources by himself. Moreover, it is considered that the human being is an individual that acts on the basis of the moral principles of the Good and the Bad, with explicit and obligatory purposes, and with a well-defined goals; when in fact the first and fundamental rationality and logic of human beings in society is that of the feeling of belonging, i.e. the tribal awareness. If political theory admits that, eventually, an individual is affected in his choices and judgments by emotional and collective factors, this phenomenon is conceptualized as a constraint for individual logic and must be separated from him in order to adequate the political theories that were made to develop individualistic logic. The individual is supposed to be separate from religious, ethnic, and traditional affiliations, particularly in the public domain. In a political perspective the development of individual logic is the key to get the emancipation of society and everything that presents an obstacle for it has to be eliminated like for example the links with affectivity and collective determinations. Ethnical or communitarian affiliation is not valorised in this approach because the personal choice between different possibilities prevailed. In other words the individual is supposed to be capable to choose the best option for his interests (rational choice).

The development of this iconic individualism is not only considered as a positive fact in moderns societies but is also the precondition to arrive at a democratic and fair society. From that standpoint, multicultural demands and requests are seen as being a step behind to what opposes ethnical roots and free will. The common aspect of these different levels of analysis is that individual development is conceived in opposition to the persistence of a supra individual entity and collective forms affiliations which are not based on the individual dimension of people's meanings. 
The best of the cases, for example, anthropological cultural perspectives such as Taylor's theory of recognition insist on the necessity of "dialogism" as an element of analysis that has to be taken into account to understand the constitution of social meaning in a multicultural society. ${ }^{12}$ In an ultimate level of argumentation we can say that this approach is the closer one to an intercultural approach, and the further from the others classical perspectives we just mentioned. This latter multicultural perspective tries to show how individual identity is built through contact with others, and through the continued exchanges which permit the Self to structure itself as an individual value and define his meanings in terms of comparison and contrast with others. Taylor localized the subject foundation in the interaction with others. For him this permits to conceptualize in a theoretical logic the artificial paradox between the individualism development and the reinforcement of collective affiliations (i.e. Ethnicity). That means that the individual's perception of himself and of his individuality depends on cognitive structure, body schemas, affinities and other qualifications subscribed in a frame that emerges through the interaction with members of the group as well as other members of other groups. In other words, the individual's capacity to conceive himself as an individual and to define qualifications of his individuality is strongly determined by his tribal interactions and social experiences. This approach seems to be inspired by the sociology of George Mead (1910) in which he argues that social consciousness precedes the physical one. This means that there is no way of getting consciousness of the Self out of a dialogical structure - and for instance the social one that emerges with him. The individual actively builds and negotiates himself through his interactions with others.

The Mead-Taylor perspective is close from an inter-subjective theory, focused on the individual as a moral entity where the importance of rootless and belonging significances in the construction of the Self is recognized. From this perspective the individual identity is conceived as empty, and that only shapes up with a life process of education and learning. This process gives individual a value system and normative behaviours, which permit him to "understand" the world and his position in it from the interior of himself Ego-centred and dramatic perceptions). Here the perspective is the opposite to the classical multicultural theories we mentioned, because not only the affiliation and belonging feeling do not represent an obstacle to individual's

\footnotetext{
${ }^{12}$ It is important to distinguish between multicultural societies, cultural pluralism and cultural diversity not only by their definitions but also by their different dimensional level of analysis that can be made. In this sense it can be said, for example, that all society is composed by cultural diversity, the State recognize cultural pluralism and multiculturalism is a paradigm centred on the political sphere.
}

Comun. \& Inf., Goiânia, GO, v. 21, n. 2, p. 87-123, jun./set. 2018. 


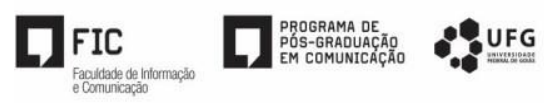

emancipation but represent the basic condition to this possibility. In that sense the interaction with others gives individuals a strong and well-structured self-meaning and constitutes a potential richness for the individuals. It is the encounter with the others, continually renewed, that permits to go forward to evolution and transformation of individual identity. At a theoretical level that allowed us to understand at the same time the clash that emerge in the heart of the self-identity due to initial belonging groups conditions and encounter with the others.

That is why valorisation and recognition of difference are the central demands in multicultural societies. These demands make us realize the framework of a single membership feeling. This framework represents the potential of the subject's identity while showing us the limits of his experiences as a single entity.

It is only with the encounter and exchange with the others that experience may have a rich and transcendental social meaning. In Mead's terms it is saying that "individual can become an object by himself' (VAN METER, 1992). The experience of difference becomes a value in itself and permits the outbreak of the inter-subjective dynamic. This also means that individual is able to make to distance from his identity and situated himself in the social evolution of change comparing his with others' identity models. From this point of view in a political philosophical language the experience of difference permits individual to have a variety of meaning options at his disposal from which he can choose.

This "dialogue theory" of identity permits to understand the importance of demands of recognition that are made by minorities. The interaction and the exchange not only puts individual in contact with others identity models, but let him to be able to observe and feel the others differences integrating them on a rational comparative logic and utilitarian dynamic. At the same time tacitly it will be a real concrete inter subjective condition. Mead and others existentialists such as Jean Paul Sartre notice the importance of others' looking at us regards (SARTRE, 1947). From this point of view all individuals addresses in an implicit or explicit way a "judgment" about the others' identities, which means that everyone is the object, in return of an analogous judgment. This dynamic could deeply affect the social actors in the process of interaction and create modifications in their identities. That means that experience with others can become as a result an under structured experience, particularly if we look at its historical and 


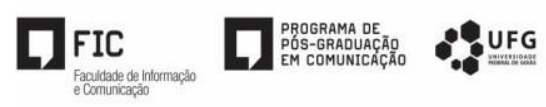

concrete sociological manifestations. From this existentialistic point of view it seems that identity is established $a$ priori.

In the interaction's process individuals can feel that the image send by others through words, gestures, behaviours are a devaluated image of themselves self and it will probably affect dignity and their own perceptions (Kinesis, proxemics and prosody). In a political and social level this is observable with whose reclaims made by members of different minorities (including women as a symbolic minority) to the mono-patriarchal-cultural majority (BERSTEIN, 1994).

\section{MASS MEDIA, INDIVIDUAL ICONICITY IN A DIVERSICAL SOCIETY}

The recognition request allows us, to understand the central role of the subjectivity in the frame of multicultural questions. The link between subjectivity and individualism is an ancient matter. The esthetical of romanticism was one of the first currents of thought to explore the feelings universe in the interaction processes and open the way of a specific modern sensibility. The psychoanalysis also legitimates the existence of the interiority; situating into a particular locus source of individual attitudes and behaviours. So the interiority and subjectivity notions are today very well expanded in social sciences and daily life. The success of these notions started in the 70's where emerged in the social scenario new formations process with new social actors: middle classes, students, young and actives women, etc. Those factors contribute to putting into a question the static positions and functions of society, where the individual only had to fill out the cases of sociological classifications (sex, age, gender, colour of skin, etcetera). This logic resulted in a new individual approach; focused it in the Self of himself, and asked new dilemmas like emancipation, wellbeing, free personal expression in public, be listening from the private scenario, etc. This individual iconicity of intimacy, interiority and subjectivity found an echo in the mass media, which made the theme of subjectivity one of the favourite topics. The cartography of the Self is huge: from the psychological paradigm to the wellbeing cult, where it is delivered to the individuals as a whole concept, from the success of intimacy testimony well "mediatized" for the media such as the talk shows, to the appearance of the medical and personal drogues, as ecstasy, Prozac, that it's to make them feel better in the relation with their own intimacy (EHRENBERG, 1991, 1995) and so on. Mass media and new information and 


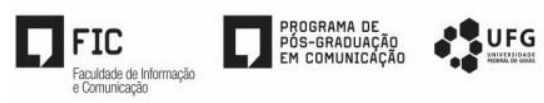

communication technologies contribute to the solidification of this type of individual public intimacy. These contribute to the development of the tribal consciousness that defines us as gregarious beings. At the same time, it promotes the fictitious idea of modern individualism, while reminding us of the need to be part of a group, and of the feeling of belonging that underlies us.

The personal interiority, intimacy and emancipation took an importance place in the definition of the individual identity. Here the link with the claim of recognition is clear. On one hand due to personal self-realization (emancipation) the subjective feeling notions central because it supposes to structure the individual identity. On the other hand this identity is constituted in terms of a dialogue, in the interaction with others, but not as a collective meaning or because the collective awareness is explicitly there or is conscienceless. In contrast the claims are from a multicultural logic where supposedly the individual needs are being satisfied, such as closing themselves in their group membership and legitimating cultural rights as members of a community. In a society where inequalities of all kinds are prevailing, while the cultural field is valued and given an important symbolic place in society, it is logical that the individual claims were in the turn of a collective cultural side; however that does not mean that it was the logic that prevails in the construction of social meaning.

So the question here is not to go in favour or against this accrual of individualism or subjectivity, more because they represent the structural forms of contemporary western societies, neither it is the issue as Charles Taylor (1994) suggested to question these dimensions and the way they impact the evaluation of a fair and unjust society, and if with that to satisfy a moral perspective (from the epistemological to the political levels); but to highlight Tribal awareness of surrounding in an inter-subjectivity dynamic.

Within this perspective is not only the monoculture epistemology that supports the political philosophy that has difficulty to integrate this kind of aspirations in its individual conceptualization of identity. It is very common that the kind of institutional responses related to the subjective multicultural claims are at the political, administrative and juridical levels, and those having nothing to do at all with the collective social meaning.

Certainly all kinds of institutional responses try to be based on a legislation that guarantees the equality of the opportunities, for example: the disaggregation of laws, the 
affirmative action programs, or the women-gender policies. On a political institutional level those actions are necessary but not enough mostly are insufficient. On an epistemological level these actions show us the distance that exists between the way social collective meaning (culture) is shaped and the way the general culture is conceptualized; i.e. they explain what creates meanings and how the ideal structure of culture is formed by other structures of a more material, and less ephemeral kind. The claims as a cultural group it is not but a demand as a material symbolic structure, and the responses are the same. From our point of view, this drives a clash between collective social meaning and materialistic social actions, a clash between dramatic perspective of life and tragic living life, a clash between individual rationality versus inter-subjective meaning, cult of individual versus

\subsection{TRIBAL AWARENESS}

All this with the violent consequences know for all, because those actions are based on a conceptualization of relations between human beings as a justice sphere and not as an intersubjectivity collective social meaning about justice. That means that a cultural matter is considered as a materialistic and justice issue where it is about formal equality access in the public space to the resources that are supposed to permit people to get the self-emancipation. Every right and responsibility has to be made in the name of the group and not through a collective meaning process inside of an inter-subjective Tribal awareness.

There are others consequences of the development of the individual subjectivity dimension in multicultural processes and analysis. For example one that concerns the conception of objectivity and trueness that also has to do with the individual self-perception of his identity and the implication on his attitude with others (ALEXANDER; SMITH, 2003). The traditional conception of truth has to do with the possible adaptation from a judgment about the state of the world. The Rousseaunian Social Contract is an example of these statements, which lose their pertinence in social meaning process and can even get in conflict with the individual description of the world. This means that truths as facts can count less in social interaction that a subjective truth perceived or lived by the individual as a concrete experience.

In a frame where there is only a true individual, the filter established by a personal experience or by an interior feeling, the emphasis is placed on the act of interpretation where 


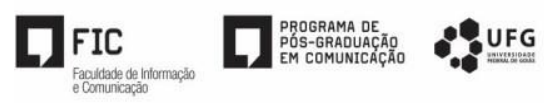

gestures, a message, any situation are integrated in a kind of hermeneutic horizon shared in a subjective and idiosyncratic level. In the chain of fabrication, transmission and reception of the signification, it is the last phase that assumes the preponderate role. In this sense the true enouncement is not more in the side of the transmission's intention or in the message itself. It is situated in the way the enouncement is felt and integrated in a collective life experience, and shared from a personal perspective. This focalization in the reception moment and in its fragmentation makes the multicultural interactions even more complex than the simple understanding of culture structures.

In that sense we understand now how a cultural sociology of imaginary perspective may analyze the epistemological, philosophical and political multiculturality reflections and actions. The main point of the debate here is about the way the individualistic perspective missed the comprehension in a social meaning constitution in daily life, getting into a miscommunication, clash mediation, and problems of translation of meanings that are involved in the interaction. For us it is a tension between a political constitution of meaning and epistemological meaning of culture. Indeed the topics of communication, mediation (by inter-subjectivity and social collective meaning), reception, interpretation and translation of the messages of social interaction are the central elements involved in the multiculturalism problems on all levels.

We argue that the analysis focused on social collective meaning in an inter-subjective relation without taking in account the individual perspective is the key to understanding how individual signifies rather a sociological invention than a concrete reality, in particular if we talk about multicultural societies. We can notice the distance that separates this approach from the liberal political philosophy where individual is defined as a moral entity and a cognitive spirit. Here individual is supposed to be autonomous and his main interest is to promote the development of emancipation. This aspect of Taylor's theory, even if it takes into account the important role played by interaction with others, makes the understanding of individual relation with the social meaning structures difficult. For sure we are dealing with a dialectic problem between individual dynamic and constitution of collective meaning. This constitution of collective meaning is only possible in the social interaction in the contact with others, but it is less taken into account in the multicultural theories and public policies where the central role is played by the Tribal awareness in the inter-subjectivity process. We will see that even the most 


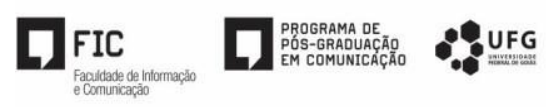

dialogical multicultural proposal as the one Charles Taylor reflects stays attached to the assumption that individual as a moral entity exists and is a central element for the analysis and for political actions. In a metaphorical sense the narcissistic Freudian interpretation of the Self is the background of all these contemporary multicultural interpretations about people's interaction.

\subsection{TRIBAL AWARENESS AND MASS MEDIA}

The sociocultural collective factors that exist in a collective imaginary or collective intersubjectivity are central in the definition of the social space. That allowed understanding why the multicultural conflicts are dichotomized in political spheres as left/ right; democrats/ republicans; liberals/ conservatives, wrong/ right; bad/ good; etcetera. As an example of the weight of this logic into the sociocultural factors we can think in the impact of mass media and ICTs. These contribute to the phenomena with contradictory logics, which at the same time they oppose that they are combined. Especially with the expansion of horizons brought about by a multitude of information and communication technologies (the so-called ICTs).

Concerning the ICTs it contributes substantially in the explosion of personal public intimacy. Here is involved in implicit or explicit way the entire individual's iconicity and the cult of the individual in multicultural societies. The mass media wrapped the symbolic value of the personal emancipation in pluralistic societies. The mass media today promote a personal spiritual status, a way and style of life that is a shared identity inscribed in a common value system with a voluntary personal motivation to participate in an "WorldWideWeb dream" (www). The ICTs and mass media are a virtual but real space with an interesting culture value from the sociology of imaginary approach. It can be used as an emblematic example about the way communication and information with a big touch of esthetical elements impact on the cult of the individual in cultural dimensions (epistemological, theoretical and political). The ICTs allow a large part of the people of the planet to identify each other, even in a contradictory way, in a clear tension of meanings of significations, as well as in full conflict of interpretations (GITLIN, 1995). This identity process is so crucial that it shows how far away from the socio-political and economic factors the mass media and ICTs could be. It is an issue that means worldwide belonging. This permits us to understand the fragile impact of socio-political and economical arguments in the understanding of social interactions. The globalization exchanges, the industrial production delocalization, the 


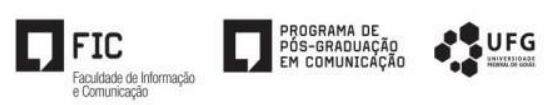

success of high-tech companies, the immaterial economy, the development of the tertiary professions as well as the mass media and ICTs, all contribute to solidifying the social meaning of belonging in a collective inter-subjectivity fact and to putting it far away from any economic or materialistic interpretations (economy, demography, professions classifications).

The popular culture, mass media and ICTs play a very important role in this process because they work as a particular industrial worldwide identification, and supposedly as a motor to the integration of worldwide dynamic tribal nomadism awareness (MAFFESOLI, 2004). The mass media, as a producer of imaginary plays a role on the inclusion into a culture dream, into a culture system of values. Tribalism and Internet is postmodernity. In others words the notion of tribal awareness permits any culture, even if it is very different (Pakistani, Indians, Latinos...) to integrate as an personal into a supra World Wide identity and offers the social meaning to have the possibility to belong to a society in a new geographical space, and by these processes make possible the conviviality in a pluralistic society. In this sense it is not an affirmative action itself, or those multicultural politics that make possible the living together between people of different cultures, but the possibility to be a part of a social meaning represented by the Tribal awareness notion. It is not a great salary policy or an affirmative action policy that makes possible the living together but the feeling that through that salary or that cultural quota the people feel belonging to a nation, to a national culture, to a common place, to a human world. In a metaphorical example being able to purchase on a consumer society at least a little item has more to do more with a feeling of being part of a world-wide tribe social meaning than with the possibility to buy something itself for a functional goal.

The melting pot only works because this collective and Tribal imaginary exists; because this social meaning works in an unconscious or conscious collective awareness inside of an intersubjective process. This imaginary is certainly individualistic, but it is working because it makes people feels as individuals feel as part of a collective meaning that is expressed by the share of at least one value: the possibility that everyone as an individual (moral entity) gets the possibility to reach this "economical" and materialistic category in a consumerist society. Here we can see how the individual iconicity (as a social meaning), and the cult of the individual as an economical and sociocultural entity (materialistic logic) are working at the same time. But this iconicity does not mean that people behave as an individual and put himself at a distance about his group of 


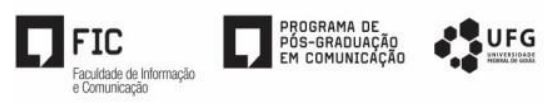

belonging. On the contrary it creates a reaction of being himself inside his belonging group (ghettos tribal dynamic). In this sense promoting without stopping a system of values such as social mobility, individual liberty, the cult of winner, ethic of ascetic individual work and responsibility, mixed with a life style of consumerism, geographical mobility, mass media apparatus, all that permits to give content and an appetence of a western identity through worldwide tribe notion.

As we said the metaphor of tribal awareness from culture sociology approach permits to highlight the iconicity of the individual in a collective interaction. It is an example to help understand how it is possible to analyse the cult of the individual or the individual iconicity in the multicultural representations. That is the paradox and the logic of individualistic multiculturalism.

Another example but of a minor nature can be provided like the case of burka or hijab phenomena in France where the claim of the Muslim origins has more to do with being a part of a global not western social meaning than with a generational transition or culture structuration. The same can be said with the six hundred Chamulas indigenous ethnic group converted to Islam in the south of Mexico. The institutional religion works here more as a shield of social ethnic meaning than as a spiritual fulfilment. In sum, the iconic individualism permits to structure the social space inducing people to adhere to its identity values, opening seducing ideals in an individualistic context, but in the other hand it clashes with the inter-subjective collective awareness creating ghettos or groups differentiations that at the end produce inexplicable violence (discrimination, racism, social marginalisation, exclusion, hate discourse) in the heart of societies (GUTIÉRREZ-MARTÍNEZ, 2008).

This paradox is also visible in the scientific paradigm, in particular with the multicultural theories, where instead of analysing culture in terms of materialistic or structural entity, the analysis must open the possibility to understand from an inter-subjective perspective social meaning and Tribal awareness. But as we know, in the most part of the sociology of culture (culture turn) these approaches have been making a legitimate political theory out of the culture paradigm. Cultural anthropology and psychoanalysis have been contributing to setting the limits of the individualistic analysis. 


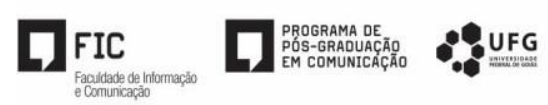

Certainly the sociology of culture offers a privilege reading for a multicultural problematic in a post-industrial society that goes far beyond the Marxist approach, but at the same time this approach has been promoting the iconic individualism. This is what we call on a political level a mono-cultural multiculturalism.

The example of this mono-cultural multiculturalism can be found with the Atlanta Olympic Games where it is possible to illustrate what we want to say about the development of the social cultural dimension from a cult of the individual and the effects of iconic individualism in society with the collaboration of mass media and ICTs. As in the case of almost all the sports events and inaugural ceremonies -the sacred ritual as excellence- (ex. Olympic games in Australia; World Cup in Russia; and so on), we all remember the opening celebration of Atlanta's Olympic games dedicated to the south of USA where the symbol of racial struggles has always had a place in the collective memory. With the association of mass media the sociocultural sphere had to deal with a non-racist America, having a celebrity like Mohamed Ali lighting the Olympic flame. We could observe through that performance a kind of strategy to manage social meaning of difference. It was a great representation in the public sphere that shows us the way the public institution handles symbols of cultural diversity. The consideration of these two elements (mass media and iconic individualism) permits to understand the creation of and after social space modification and drives us to an interesting semiotic analysis; i.e. it is possible to see how in a symbolical binary analysis the perception of the cultural pluralism changed with the playing of a social meaning. This let us to understand the question of how multicultural societies are dealing with the cultural diversity, and with the association of mass media and ICTs concerning this issue the "culture war" can be understood them as a way to control or to conquest the space of representations and symbols in social meanings. This can be understudied as a struggle to modify the semiotics force relations in order to work on the conditions of production, circulation and distribution of the social narratives.

These events like the Olympic Games and Soccer World Cup are obviously very wellknown and just show us the role of mass media in the way the public sphere handles multicultural problematic, but tells us as well in a schematic way, the development of state policies and the creation of collective imaginary about how to deal with the cultural diversity (creation of stereotypes). The ICTs will become not only a simple mirror of multicultural societies but also a 
place where the identities and values are elaborated, negotiated, diffused in a contradictory way. At the same time this offers a multicultural scope meaning an acceptance of the difference, contributing to conform it. This phenomenon is called homogenization of differences. Communication is a social cement, but of a tragic nature (Nietzsche), because this cement is not necessarily good or bad. From there we extract the idea of synthesis-tension, contrary to a conclusive synthesis. Is not communication just this synthesis-tension of a tragic nature? It does not matter the information (the content), since we communicate with others.

Marcel Gauchet (1998), who thinks in terms of an age of identities, argues that cultural diversity is a powerful mask for multiculturalism's homogenization of minds, attitudes and sensitivities. Today while it is supposedly required to adopt a preference or culturally specific orientation, it is not in the name of "polytheism of values" (Weber), but rather because of a hegemonic process of privatization of lives, and especially social meanings.

These superficial analyses about mass media and ICTs in cultural events, tell us how multicultural and individual logic paradoxically come together and create differentiation's sight of cultural diversity in daily life in a deep side of our inter-subjectivity, and show the impact of the iconic individualism. But the most important aspect about this has to do with the issue that in contemporary societies more than ever it is a matter of a communicational paradigm that considers the generalization of the communicative fact as the principal characteristic of actual societies (MEYEROWITZ, 1993). As we argue here, one of the biggest problems with the multicultural approach, even the most dialogic ones (Taylor, 1994) are dealing with a communicational exchange between groups in a collective meaning dynamic. Obviously this on the contrary communication can create conflicts between the different groups, which most of the times are conflicts about the symbols control, and their references, or just conflicts to accept those imposed symbols, and be able to arrive together to a decision that people can live with (TERDIMAN, 1995). That is crucial especially if we are talking about societies where individualism and interiority are as important as icons of sociocultural identity constitution. In the topic communication is as Michel Foucault said, "it is power to name things": after denomination comes domination.

In a political level and in everyday the communication paradigm is not only a usual problem but a very though one to resolve. Illustrating about what we are making reference, we 


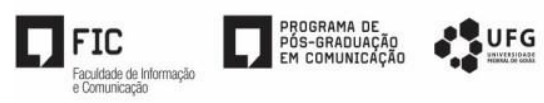

take for example the "metaphor of the hut". Suppose another person from a different culture for some reason has to stay indefinitely in the house where we live and we own or at least we rent. In this case, the house represents the state. The new tenants represent migrants, and public policy the owner. Now the question is: how many of us would be willing to make an agreement that rules of governing the coexistence in the house, implying that this agreement can change the rules previously established which means changing some of our previous behaviours and daily dynamics? If we look from the perspective of political regimes we would see as the multiculturalist paradigm Republican answers before this dilemma. New tenants must adapt and follow the rules already established. The argument is that there is a social contract whose rules are universal and inalienable and they are for the good of all. A multicultural liberal rate regime would establish that each one in his private space apply the customs that dictated its own culture (of course without interfering with public morals with violent family behaviours of all kinds, etcetera). Regarding public space, the rules applied just as the republican: everyone must adapt to the rules of the house in the common spaces. In an inter-subjectivity coexistence, with the arrival of new tenants the established rules would be broken again in the house in both private and common areas. How many of us will accept to change the rules of our house to accommodate a foreign visitor? Here is where probably we can make a difference between sociology of culture and culture sociology in the analysis of multicultural theories versus inter-subjectivity theories.

In this logic as much as social space becomes a sociocultural meaning and a fact of communicational paradigm it coexists with the semiotic sphere (LOTMAN, 1990) where the meanings and values that are in circulation, conform the belonging feelings and the ways in which people and groups define their position of belonging and the meaning of their actions. That brings us to the interpretation problematic and the importance of the narrative relation that link people with groups, or individuals with groups. That means that the social space defined as a hermeneutical semiotic space permits on the analysis level to make visible the interaction as a result of production, circulation and interpretation system with collective meanings, with mutual participation in different degrees of people involved in the constant interaction. This is what we call the general social semiotic hermeneutical space. This is a simple matter of translation dynamic. 
In resume, this is the proposal when we refer to the logic of inter-subjectivity theories and Tribal awareness, i.e. analyse the multicultural paradigm (epistemological, theoretical and political) through the interaction theories in terms of translation (LEPENIENS, 1994). That means on an epistemological level analysing how cultures exchange social meanings in the sphere of diversity. Diversity and exchange are considered as anthropological elements of all societies of all times. We consider that this overrules the binaries system of analysis. ${ }^{13}$ On a theoretical level it means the way interaction and collective inter-subjectivity create social meaning and how the struggle of this creation of meaning conforms the relations between formal and informal sphere; i.e. the legitimate and not legitimate levels. On a political and everyday level of analysis this signifies that the possibility of living together among cultural diverse systems with many social meanings depends on the capacity to find through interaction, equivalent meanings that allow confrontation, hybridization, combinations and a common living agreement.

\section{CULTURE ANALYSIS IN A MULTICULTURAL POLITICAL SOCIETY:} RECEPTION + INTERPRETATION + TRANSLATION = SOCIAL MEANING

This inter-cultural approach obviously allowed us to go beyond the materialistic dimension of the analyses, at least in the first approaches, and to not essentialise political classification and materialistic concepts of people (i.e. demographic, economic, etc.). This approach considers that multicultural societies are those penetrated with the demand of recognition and respect of differences (in the best case, promoting a dialogical multiculturalism as Charles Taylor proposed), but impregnated with iconic individualism that creates a paradoxical logic that puts the inter-subjectivity in a ghetto logic in the way the social meaning is conformed. In other words it leads us to the analysis of an individualistic multicultural society.

It is true that the individual as a concept is linked with an issue of imprecision, but it is certain that we can relate it to the advance of what is called Modernity. As we said the social science, and mostly the explicative sociology approach were created to analyse the Modernity

\footnotetext{
${ }^{13}$ It is certainly that Lévi-Strauss shows how mankind and societies share the binary system of interpretation. For us that is true if we focus in a theoretical level, or in a epistemological level of second order, means in the societies order or human being interaction, but not in the meaning level that is a Prime epistemological level because meaning do not depends in a fact of decisions about what is good or wrong with whatever symbol or image is in front of me, but what it means is what that symbol or image communicate to me in reference with others. We do not refer communication as a materialistic sense, but in an emotional signification that appeals the humans' common senses (smell, mind, touch, etc.). This is what we call imaginary.
}

Comun. \& Inf., Goiânia, GO, v. 21, n. 2, p. 87-123, jun./set. 2018. 
idea based on contemporary western society's ideals. In that sense the concept of individual seems to also include a methodological paradigm based on a dramatic point of view of society. In this way we affirm that the cult of individual reflects a kind of behaviour that privileges the selfretreatment into his own private sphere and at the same time is a kind of crypt of authenticity in a public sphere (individual iconicity) in the modern world that paradoxically rejects the traditionalisms and old normativity. Some authors call this dynamic the methodological individualism (BIRNBAUM; LECA, 1991) in opposition to the social holism argument by Louis Dumont (1983). Our proposal it is not to define individual as a pejorative matter (because that is a moral issue) but to understand both sides of what the individual logic does to the epistemological, theoretical and political multiculturalism levels (paradigm). With the concepts of Iconicity of the individual (private sphere, authenticity, intimacy, subjectivity...) and the cult of the individual (public, homogenization, rationality, autonomy...) we seek to understand social meaning in a collective inter-subjectivity dynamic (Intercultural paradigm).

This approach takes distance from the multicultural paradigm where most of the time the theoretical level discussion is about whether the cultural diversity interaction concerns the existence or not of a contradiction with individual ethical narrative that is supposed to be autonomous, conscious and own his surroundings. In other words the theories discuss if the multicultural proposal produces cultural struggles with a relativisation of the communitarian values or if individual as a moral entity is a privileged value in the interaction for modern societies.

For us in an epistemological dimension we want to analyse that Modernity is linked with individualism values, and all that predominates social sciences, democracy and multicultural paradigm (theories, concepts, policies) (ALEXANDER; SMITH, 2003). ${ }^{14}$ That means that we are talking about a cultural global system of beliefs that can be analysed through the cultural social meaning approach giving us as a result the intercultural paradigm.

This classical discussion contains a moral debate, i.e. if the multicultural paradigm is an option for deliberative and representative democratic societies in order to get the free autonomous individual self-fulfilment in society (that is a modern and western value). The debates around the multiculturalism paradigm are inscribed in two propositions. One is about a system that enforces

\footnotetext{
${ }^{14}$ The sense we are giving to democracy is the representative and deliberative democracy, and not as a tool of a civil sphere.
} 
the communitarian identities and the other one is about enforced the self-fulfilment individual ethic. Here it is an epistemological discussion. I argue that the individual is an iconic element of social meaning but do not describe or represent the collective inter-subjectivity dynamic that is the dimensional form of social meaning before even the social meaning production. In other words the individualism is the circumference of a social modern phenomena and not the main element. The individual as a moral entity is the crucible of appearances (MAFFESOLI, 2007). It is the metaphor to describe the dynamic that goes from individual esthetical to the collective ethic. The ICTs are only a technical element that mediates these two social dimensions.

To be able to highlight this crucible metaphor about culture describing the cult of individual as a spirit of time and the individual iconicity as personal social meaning can be useful. I already mentioned some ideas about the cult of the individual. Concerning the individual iconicity I can say that as social mass phenomena take place mostly in the sixties after the Second World War with the policies of securization of western societies. That would mean that the cult of the individual that emerged mostly in XIX century would impact directly people's intimacy. Indeed with the rise of the market economy, the democratization of politics every action is made to privilege the individual decisions in the most complete possible autonomy without the acceptance or permission of communitarian determination. The social security, the individual vote, and those entire political and economic elements made people feel less and less dependence on the group and others. The individual is projected as a reflexive entity not sharing a common destiny (EHRENBERG, 1995). It is in a way several actions to breakout the collective action. In other terms the common shared solidarity of people in the civil sphere has been compacted in "crypts of social necessity". This means that the collective inter-subjectivity does not disappear or is eliminated but goes under the individualism dynamic.

The sacralisation of individual as political and philosophical phenomena is known to go back at least two centuries. The individual iconicity as an intellectual and preliminary mental statement appears with the national State and Republican state creation with the establishment of the well-known Social contract. But it is not until the middle of the last century that it embraced the entire societies in every day's life. With the installation of modernity principles and Social contract that contains philosophical political values the individual iconicity as values and central elements of sociality would consolidate one century later as a tube conductor of contemporary

Comun. \& Inf., Goiânia, GO, v. 21, n. 2, p. 87-123, jun./set. 2018. 
societies. ${ }^{15}$ The creation of State, democratization of political societies, urbanization, modern economy, self-fulfilment of individual capacities, specializations jobs, etc. are, as Karl Popper would say, are the elements to make the transition from a closed society to an open one. That means the transition from societies where every single life is determined by the chance of birth to a society where the governance is given to individual responsibility and self-initiative (POPPER, 1979). It is known that on an intellectual level the importance given to the individual iconicity goes back in time with to the Quattrocento elitist Italian movement in the XV century. As we know this movement aspired to distance from Middle-ages (Dark ages) when the individual was consider been constrained in a collective political determination. Later on in the XVIII century the seeking for authenticity and subjectivity ideals gives to the individual iconicity a remarkable importance. Backs at that time the individual was associated with the idea that the people's destiny depends on every one and not on an abstract collective entity. In that time the philosophers expressed in terms of human nature the definition of the individual, they talked about truth of the self, situated in a deep and intimate side of every one, far away from the sociohistorical and cultural contingences. It is supposed that the surrounding does not define people. Even the Romantics writers make a cult of the self where the emotions and experiences of individual are expressed in exaggerated literature and artistic forms. It is probably not necessary to mention the "invisible hand" proposed by Adam Smith where the collective interest constrained the search for the individual interest. This economic cult of the individual is a part of the self-regulation economic theories that are still popular at least at the socio-economical organization level of today's societies. ${ }^{16}$ Finally with the ICTs the phenomenon became exponential.

All these ideas did contribute to the privatization of life, embraced the reflexive and psychological aspects of people, mobilized intimacy in the process of personal identities (elements of the individual iconicity) and reinforced the modern cult of the individual where the values of $i$ ) individual emancipation and $i$ ) individual free choice become the central elements.

\footnotetext{
${ }^{15}$ We can even go far away on time two thousand years ago as Dumont propose to find the roots of the individualism as a system of values. But we stay in this particular paper just with the secular modern period of time.

16 The self-regulation theory as we can see reflects in a very strong way the Charles Taylor proposal, but in the level of economical interactions and exchange, but that interaction and exchange goes in a individual meaning, and not in a social collective meaning.
} 
These elements would take form in an esthetical transfiguration with the authenticity, intimacy and privacy values decades after.

Individual emancipation is for sure a political and moral conception that refers to individualism as a strong belief of modernity. That supposes that every human being has the possibility to be autonomous from collective and institutional frames. It is not a denial of social and state institutions but just a relativization of the institutional narratives as the ultimate goal. It is not exactly a rupture with the traditional collective frames but supposedly the end of the individual enforced consciousness or unconsciousness to the submission of this collectiveness. The belief of the individual emancipation to determinate himself passes through the independence of family, clan, origin religion, corporation, group, and from the sociological arbitrary conceptions such as binary sex, neighbourhood logic, nationhood, etc. That does not mean that the individualism installs a society without normativity, it means that that normativity is dictated by individual identities and imperative contract of those identities. All these phenomena drive to different logics that may go sometimes in contradictory directions. Indeed the individualistic logic points to the self-centeredness, search of the wellbeing consumerism, extreme leisure, cult of the body and health, a development of a relational sense and a rise of communication with others, at the same time as rise of tolerance to others, pluralistic sensibility, and a protection of the environment feeling (LIPOVETSKY, 2004).

When every human is considered an individual and has a social value it seems that everyone would look for his own inner self (PALANTE, 1992), and tells us that the cult of the individual as a product became iconicity and enforces the procedural democracy societies. ${ }^{17}$ In a multicultural paradigm the logic is the same but with the extended argument that considers individual as different from everyone, and this difference today is supposed to be the common feature shared by everyone. The individual and its additions is the legitimate source of values,

\footnotetext{
${ }^{17}$ As we said the values of the cult of individual are in the heart of democracy system. Democracy is in this way a political organization that in its principles makes the enouncement of the individualism. In that sense democratic societies disqualify the religious, moral, and absolute traditional institutions as entities with the power to dictate the law and deliver knowledge about how the exchanges should be organized, leaving it to the power of individual's rationality. In that way the men can decide in a legitimate form how to share political, material and symbolic power in the heart of collectiveness. The individual society built itself in a pluralistic and liberal co-existence where nobody is submitted to any doctrine but by a collegial decision coming from individual choices. That seems to be the very logic to organize people in complex societies, but we know that the meanings and mostly the social ones are not conformed through an addition of individual choices. Democracy supposes to responds to the individualistic aspirations, adding them one to another. And obviously placing the individual as the ultimate referent of the system, as a sacred entity he becomes free and equal to all others.
}

Comun. \& Inf., Goiânia, GO, v. 21, n. 2, p. 87-123, jun./set. 2018. 


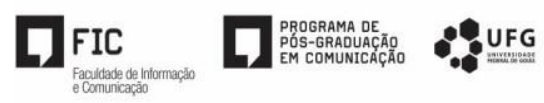

normativity and knowledge. That means as well that everyone can live in their own way of life in coexistence with others in a shared of power that supposedly does not come from a particular doctrine. The point is that we wonder if the individual is not a doctrine itself or a sacred element of a larger system of beliefs that we call Modernity.

In that sense societies in Western liberal democratic spaces encourage more than in the past the reactivation of identity marked in terms of origins and culture differences. That is how the multicultural paradigm passed from the individual egalitarian conception to the promotion of individual difference. It looks as if we could not grow as a person without reference to his collective identity marks, as if the marks of community belonging would be broken if we do not assume an inscription group. In other words looks like it is impossible to get a collective identity without identification to a group. Giving the man an exclusive legitimacy in making decisions, individualism made him the supreme repository and takes his as the fundamental element of democratic system. There is not real opposition to the classical principles of individualism but rather a reproduction of this dynamics. This is why we argue that this "basic" multicultural logic reflects the primitive roots of individualism as Dumont describes.

The purely individualistic multicultural imperative becomes, in the contemporary context, an awareness of origins within nations that recognize cultural and ethnic plurality. However far from being a vehicle of liberation, the nation, which once carried the ideal of emancipation, is now suspected. In fact, this same ideal is now seen only as a pretext for cultural uniformity through the preponderance of the majority culture that is supported by the iconic individualism. In addition, the nation calls for action, and thus obligation on behalf of the collective cause, it embodies an out-dated civic responsibility and the installation of state borders at a time when the boundaries have become unbearable exclusive.

Equalizing and homogenizing human and civic dignities in a democratic regime supposedly rejects the formal statute of traditional institution from the ancient regime. In this sense it is true that the declarations of human rights in almost all the modern societies are the foundational political modern text of democracies and individualistic societies. The same happens with the creation of National States because to legitimate itself prolongs the individual principle of emancipation in the logic of people emancipation defined as a collective entity. The nation is an arbitrary construction that mythicized the state as an object of self-determination in a 
movement that goes from a collective conscience that desires to live by their own choices and laws in order to govern collective life to an imagined community individualized in one concept (ANDERSON, 1983). For Louis Dumont the state-nation is exactly the type of global society that corresponds to the individualistic kingdom as a social value (DUMONT, 1983). ${ }^{18}$

As we were saying the reference to a consciousness of collectiveness in interaction with others is the foundation of every social meaning. It is the foundation of culture as a sociological category. In that sense it is probably naive to conceive that people will leave their ethical groups values in the public space, or in a catalogue of individual values. In our perspective this is why the multicultural paradigm (theories, policies, etcetera-) may clash in public sphere, civil sphere and every day's dynamic.

The question for us is to make visible how at the first moment a sacred element as the individual, and then his iconicity got legitimized on the ethical level, i.e. so that every ones feels as a shared collective social meaning that the logic of human being is represented by the individual morality. Multiculturalism has become part of the aspirations of everyone's choices especially when the cultural referent is the origins because that seems to be the key to access to the ideal of authenticity that is promoted. Here we find a link between individual identity and collective identity with the emergence of the multicultural communitarian current. As if his success is due to his ability to combine the reality of ethno cultural pluralism and the primacy of undeniable liberal values. Credibility is taking into account precisely in the name of values of human dignity and individual freedom, those are supposed to be the limits of the cultures of origins that are promoted. With the association of mass media, communication system, ICT's and the state as an institutional authority entity this paradox mentioned before creates a society of exclusion and inclusion, that which drives us to the question of power in a multicultural society or to the topic of the violence of the state.

\footnotetext{
${ }^{18}$ The spirit of initiative and the obligation that everyone becomes himself (the cult of individual) is the equivalent of the interiorization of decisions and responsibility of power represented by democratic societies. In this system of beliefs the individual rights and interests supposed to be above the collectives' ones. This contradiction exists on all the levels, and in everyday life we have to deal with the individual dynamics in contradiction with collective meanings, especially if we talk about topics of health, education, life and death (Bioethics).
} 


\section{EPILOGUE: TRANS-INTER-CULTURALITY AS AN INTER-SUBJECTIVE COLLECTIVE DIALOGUE}

These approaches seems to be close to the inter-subjectivity social theories, but these are still multicultural theories too focused on the individual as a unique - sole, exclusive element of the system. This subtle but important difference makes possible a complete different analysis about society. Indeed, in the last decade the cultural diversity claims have come through the argument that respect and recognition are not sufficient to live within cultural differences in a fair society. They claim that it is necessary to go forward and to know social-culture meanings by interacting, exchanging and in dialogue process with all the groups involved in order to find ethical common points of view about living in a society (intercultural approach). Note that this dialogue is fundamentally constituted by conflicts of interpretations and communicative tensions between the parties. In this sense at a political level it is not only a matter of recognizing cultural differences and accepting different forms of citizenship (rights and responsibilities -multicultural approaches), it is also necessary to promote the dialogue among cultures, the interaction itself. In other words, it is not only a matter of respecting different cultures but living with them in a logic interaction and exchange, even if it is conflictive and asymmetric. This approach moves toward to what someone will call a collective multiculturalism (Charles Taylor) or that others will define as an individualistic interculturality (cultural anthropology). Anyway, the common point in all these approaches is that the interaction is necessary to break down the logics as a ghetto.

The discourses of multiculturalism promote the contemporary idea of the development of identity through recognition of the minority identity. Proponents of multiculturalism believe that individuals cannot flourish without relying on the system of their community affiliations. And this is why they defend minority rights: they intend to protect the minority cultures from discrimination and degrading crushing domination of the majority culture. In this sense the multiculturalism paradigm tends to reveal a critical dimension to community boundaries by recognizing officially (i.e. from the State) cultural minorities within societies, but what it results in is the "essentialization" of the collective ownership of an individual identity. This dynamic reifies identities and ultimately describes the collective individual only as being a member of his community of belonging. This is the version that some authors affiliated to the multiculturalist camp, such as Sylvie Renaut (2002) or Will Kymlicka (2001), point defined as the real 
multicultural societies. They assume that individuals should be free to remain in their original cultural community, to leave and possibly choose a new one. These "new" communities fall into the effect of the "elective identities" whose members are supposed to choose "freely" and to adopt the traits of the groups, while they remain free to abandon it, perhaps to move on to another identity (VIBERT, 2002). This remains a dramatic point of view of humans' interactions.

Multicultural theory outlined by Kymlicka (2000) reveals all the limitations that may have a conception of culture defined as a context of choice. As Parekh (2006) pointed out, if human nature is always shaped by a culture and if the personality of individuals develops within cultural models historically situated, multiculturalist's approaches should consider instead cultural diversity as a vital moral good value. Humans require a rich and strong culture, but also a culture that provides them access to others. The thesis of coexistence between identity and culture is one of the fundamental ideas of contemporary hermeneutics anthropology (GEERTZ, 1988; 1999). In that sense Multiculturalism cannot be reduced only to a some kind of morally violent practices such as female circumcision, or other forms of sex mutilation of women and men (circumcision), or forced marriages, fairly common among some Muslim communities or countries (Chad) or immigrant communities in Western countries. Moreover, Muslims, for instance, can also find in our societies a wide range of phenomena they can legitimately condemn as for example minors abuses, sexual perversions, surgery modification of the female body, etcetera. This drives us to another particular critique made against the multicultural paradigm in the name of individual freedom. It is the question which, by involving the defence of minority cultures when these aspects include a cultural transgression, not only because they strike a Western sensibility, in which case the reaction would be ethnocentric, but because they bully dignity and human freedom-thus affecting universal values. Others argue that these practices were nevertheless a choice of their "victims". Still, the idea of a freely chosen practice means that it is voluntary, conscious, free from pressure or peer pressure, or from the weight of forced traditions.

In this sense Seyla Benhabib (2005) defends the prospect of a complex cultural dialogue. This dialogue assumes that human beings can disagree and even refuse clearly certain aspects of practices and customs of other cultures, such as the subordination of women - without devaluing or denigrating their entire culture, and Cosmo-vision that are incorporated. 


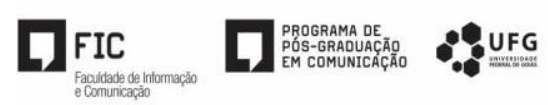

In this sense Heidegger calls for a concept of donation that implies that every culture is something irreplaceable in terms of spontaneity, pluralism and human diversity. Theorists would say that the gift value of each culture must be measured by its ability to give something special and absolutely unique in terms of multiple modes of being in world. Recognized in every culture a free gift is somehow to recognize a kind of a debt. Marcel Mauss (1924) showed in his famous study about don and contre-don, how a culture is able to seal an alliance with people who were considered as enemies before (CAILLE, 2007; HÉNAFF, 2002). Today we can call this as reciprocity. Parekh (2006), in turn, suggests the idea of bifocal dialogue among cultures. He argues about initiating such a dialogue when the majority defends their constitutive values against a minority who defends the practices that have been condemned. Moreover the existence of mistrust between the groups in dialogue sometimes can be excessive, due to different values and no common interests. An acceptable answer for all these questions that regard practices can always be found on a bifocal dialogue. If intercultural dialogue is complex in the sense of Benhabib, it is precisely because it does not take place among cultures that are conceived as holistic and essentialist, as if they were monolithic and opposite. Cultures are conceived here as entities in constant communication, transmission, interpretation and translation of social meanings in an inter-subjective dynamic being with interpretative conflicts and communication tensions.

François Jullien (2008) has rightly pointed out that genuine communication among cultures requires designing the etymology of the terms of dialogue. The logos return indeed to a common intelligibility sense of life while the dia refers to the gap between the views of stakeholders and the diversity of their differences (social, linguistic, political, religious etc.). In others words, dialogue is the translation of different social meanings to make possible a common interpretation of, at least, one of the elements of the social meaning. Indeed, the problem is not to restore a hierarchy of cultures from an ethnocentric assertion. The assumption of equal value in the different cultures has to do more with the complementarity of cultures than hierarchical accommodations. Their mutual relative translatability (but not absolute) and the awareness of their transformations through their incessant conflict dynamics allow maintaining immanent historical formations alive. It must be recognized that every culture is not only a particular 


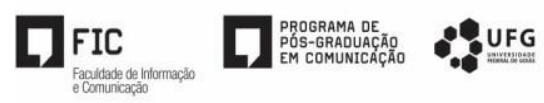

expression of human plurality, but also the condition of self-respect, since it is publicly recognized and affirmed as those who share than those who do not.

Weber's definition of culture emphasizes the value that individual and collective life must represent, in relation to the production of meanings and the attribution of meanings associated with it. To Weber the concept of culture is the point of view of man, a finite segment of the meaningless infinity of the fate of the world, which gives sense and meaning to real life (WEBER, 1992). In this perspective the concept of transculturation is not based on the claim that cultures are homogeneous units and circumscribed in stable boundaries. The boundaries are not established by the nations, religions, ethnicities and traditions, but in the complex dynamics of human networks and their flexible interactions (SANDKÜHLER, 2004). The origins are supposed to change as well. This is part of what we want to say when is used the metaphor of Tribal awareness.

Pluralist paradigm emphasizes that multiculturalism refers simply to the coexistence of different cultures within the same geopolitical space; interculturality refers to the dynamic, enabling exchanges and reciprocal relationships among groups of multicultural melting pot, so what breeds ethnocentrism and prejudice. The concept of transcultural indicates not only that we establish relationships with each other but also that we adopt towards others an attitude of empathetic acceptance.

Beyond the inflection of a psychological nature, the concept of transculturation is very close to the concept of interculturality. This has been advocated by many researchers for critizing the gaps and overcoming the limitations of the concept of multiculturalism. Indeed, while recognizing the rights of cultures and the need for mutual respect, multiculturalism unlike the intercultural approach, that hardly takes any or show little interest about the problem that represents the conflicts among cultures and their peaceful resolution, just emphasizing the need of building unity in over diversity (ROMERO, 2003; FLAPE, 2005). Adopting constructive criticism is to refute any radical antithesis between the concepts of multicultural and intercultural.

When cultures confront each other, they are still determining practices and beliefs that are at stake and not strictly defined in homogeneous totalities. A person or an individual can condemn, for example, the ancient Chinese tradition of foot binding, and at the same time admire the calligraphy, pottery and commitment to the value of honest work of Chinese culture 
(BENHABIB, 2005). Because of their porous nature and internal plurality, cultures interpenetrate and change constantly. Cultures develop themselves in a process of osmosis, translation and hybridization, by interacting and influencing each other, even when they seem to be in relentless conflict. However, intercultural dialogue should not only bring out the points of agreement. It must also disclose the points of division and dissension to help others to prove their identity by accepting either to challenge or to be critical with him (ZAMAGNI, 2002). We should not underestimate the potential inherent in complex cultural dialogue. Reflection on multiculturalism must foster dialogue on cultural identity of communities within the public space, especially around the dialectical relation between majority and minority cultures. Only dialogue can promote public interleaving in a reciprocal exchange between cultures. It can also lead to open conflict among the sociocultural narratives. But conflicts with the intensity of the process of communication and discussion and forms of understanding within civil society in the civil sphere can lead to a re-appropriation and transformation of cultural heritage (cf. Solidarity -Alexander 2006). A confrontation of this kind contributes to the definition of justice and injustice relations among groups (BENHABIB, 2005). It is within the space created by this cultural dialogue that complex confrontation between-groups must take place.

\section{REFERENCES AND BIBLIOGRAPHY}

ALEXANDER, J.; SMITH P. The meanings of Social Life. A cultural sociology. United Kingdom: Oxford University Press, 2003.

ALEXANDER, J. C. The civil Sphere. United Kingdom: Oxford University Press, 2006.

ANDERSON, B. Imagined Communities: reflections on the origin and spread of nationalism. London: Verso, 1983.

BENHABIB, S. La revendicazione dell'identità culturale. Eguaglianza e diversità dell'era globale. Bologna: Il Mulino, 2005.

BERSTEIN R. Dictatorship of virtue: multiculturalism and battle for america's future. New York: Knopf, 1994.

BOUDON, R. Dictionnaire critique de la sociologie. Paris: PUF, 1982. 
BIRNBAUM, P.; LECA, J. (Dir.). Sur L'individualisme. Théories et méthodes. Paris: PFNSP, 1991.

CAILLE, A. "Reconnaissance et sociologie". In: La quête de reconnaissance. Paris: La

Découverte, MAUSS, 2007.

DELUMEAU, Jean. Historia del Paraíso. El jardín de las delicias. Barcelona: Taurus, 2005.

DUMONT, L. Essais sur l'individualisme. Une perspective anthropologique sur l'idéologie modern. Paris: Seuil, 1983.

EHRENBERG, A. Le culte de la performance. Paris: Pluriel, 1991.

L'individu incertain. Paris: Pluriel, 1995.

GAUCHET, M. La religion dans la démocratie. Parcours de la laïcité. Paris: Gallimard, 1998.

GEERTZ, C. Antropología interpretativa. Argentina: Siglo XXI, 1988.

Mundo Global, mundo local. Argentina: Siglo XXI, 1999.

GITLIN, T. The Twilight of common dreams: why America is wracked by culture wars. New York: H. Holt, 1995.

GRASSI, V. Introduction á la sociologie de l’imaginaire. Paris: Érès, 2008.

GUTIÉRREZ-MARTÍNEZ, D. Revisitar la etnicidad. Miradas cruzadas en torno a la diversidad. México: Siglo XXI, 2008.

HÉNAFF, M. Le Prix de la verité. Le don, l'argent, la philosophie. Paris: Seuil, 2002.

JULLIEN, F. De l'universel, de l'informe, du commun et du dialogue entre cultures. Paris: Fayard, 2008.

KYMLICKA, W. La citoyenneté multiculturelle. Paris: La Découverte, 2001.

KYMLICKA, W.; MESURE S. (Dir). Les identitiés culturelles. Paris: PUF, 2000.

(Comprendre, 1).

LASCH, C. The culture of Narcissism. New York: Norton, 1979.

LEPENIENS, W. La traducibilità delle culture. Intersezioni, [S.1.], n. 14, avril 1994, p. 5-19.

LIPOVETSKY, G. L’ère du vide. Paris: Gallimard, 1983. 
. “Individualisme”, Guide Républicain. Paris: Delgrave, 2004.

LOTMAN, Y. The universe of Mind. London: Tauris, 1990.

MAFFESOLI, M. El tiempo de las tribus. El ocaso del individualismo en las sociedades posmodernas. México: Siglo XXI, 2004.

2007.

En el crisol de las apariencias. Para una ética de la estética. México: Siglo XXI,

MARTUCCELLI, D. Sociologies de la modernité. Paris: Folio Essais, 1999.

MAUSS, M. Essai sur le don, in Sociologie et anthropologie. Paris: PUF, 1924.

MEAD, G. H. What social object must psychology presuppose? Journal of Philosophy, Psychology and Scientific Methods, [S.1.], v. 7, n.7, p. 174-180, 1910.

MEYROWITZ, Joshua; MAGUIRE, John. Media, place, and multiculturalism. Society, [S.1.], v. 30, n. 5, p. 41-48, 1993.

PALANTE, G. La sensibilité individualiste. Paris: Folle Avoine, 1992.

PAREKH, B. Rethinking Multiculturalism. Cultural Diversity and Political Theory. Basingstoke: Palgrave Macmillan, 2006.

POPPER, K. La société ouverte et ses ennemis. Paris: Seuil, 1979.

RENAUT, Alain; MESURE, S. Alter Ego, Les paradoxes de l'identité démocratique. Paris: Flammarion, 2002.

ROMERO C.G. "Pluralismo, Multiculturalismo e Onterculturalidad". Educación y Future, [S.1.] n. 8, 2003.

SANDKÜHLER H.J. "Sapere pluralismo e dirito". In. FINELLI R.; FISTETTI F.

Globalizzazzione e diritti future. Roma: Menifestolibri, 2004.

SARTRE J. P. Huis Clos. Paris: Gallimard, 1947.

SENNETT R. Les Tyrannies de l'intimité. Paris: Seuil, 1979.

TAYLOR C. Multiculturalisme. Différence et démocratie. Paris: Aubier, 1994.

TERDIMAN, R. “The politics of Political Correctness". In: C. NEWFIELD; R STRICLAND (Dir.). After Political Correctness. Boulder: Westview, 1995, p. 238-252.

VAN METER, K. Sociologie. Paris: Larousse, 1992. 


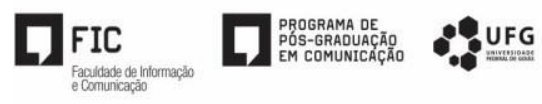

VIBERT, S. "La démocratie dans un espace "post national"? Anthropologie et Sociétés, [S.1.], v. 26, n. 1, 2002, p. 177-194. Disponible en: <https://www.erudit.org/fr/revues/as/2002-v26-n1as472/000709ar/> Accès en: 07 oct. 2018.

WEBER, M. "L'objectivité de la connaissance". In: Essais sur la théorie de la science. Paris: Presses Pocket, 1992.

ZAMAGNI, S. “Migrazioni, multicuralità e politiche dell'identitè”. In: VIGNA, Carmelo, ZAMAGNI, Stefano (Dir.). Multiculturalismo e identitè. Milano: Vita e pensiero, 2002. 